... Župčić, Vlaović, Domljan, Grbac: Influence of Various Wood Species and Cross-Sections...

Ivica Župčić, Zoran Vlaović, Danijela Domljan, Ivica Grbac ${ }^{l}$

\title{
Influence of Various Wood Species and Cross-Sections on Strength of a Dowel Welding Joint
}

\section{Utjecaj vrste drva i presjeka na čvrstoću zavarenog moždanika}

\author{
Original scientific paper • Izvorni znanstveni rad \\ Received-prispjelo: 5. 4. 2013. \\ Accepted-prihvaćeno: 9. 4. 2014. \\ UDK: $630 * 824.4 ; 630 * 824.52$ \\ doi:10.5552/drind.2014.1324
}

\begin{abstract}
Rotation welding is a new method used in wood welding. Heat that develops due to the friction on contact surfaces softens and melts the wood structure (melt is produced). When the friction stops, the melt cools down and solidifies forming a firm joint.

This research is based on the examination of the influence of various wood species and cross-sections on the strength of joints produced by rotational welding. Using rotation frequency and shifts in the orientation of the horizontal axis, a beech dowel is welded to a base made of common beach (Fagus sylvatica L.), pedunculate oak (Quercus robur L.) and Norway spruce (Picea abies L.) (hereinafter only beech, oak and spruce). Welding direction is both parallel to the orientation of the base fibres $(P P)$ and perpendicular to the orientation of the base fibres $(R, R T, T)$.

Research results indicate that the dowel welded to the beech base retains the largest strength, whereas the dowel welded to the spruce base reveals the weakest results. Based on the research results, it can be concluded that beech dowels welded in the direction of beech and oak bases have the best strength of a joint. In spruce samples, reaction wood was used (compression wood in conifers) with somewhat different distribution of strength depending on the welding direction.
\end{abstract}

Key words: welding of wood, dowel joints, withdrawal strength, embedded force, wood species, anatomical orientation

SAŽETAK • Rotacijsko zavarivanje novija je metoda spajanja drva. Zbog trenja na kontaktnim površinama pojavljuje se toplina koja omekša i rastali strukturu drva (nastaje talina) te se formira spoj. Prestankom trenja drvo se hladi i talina otvrdnjava te nastaje čvrsti spoj.

Istraživanje se temelji na ispitivanju utjecaja vrste drva i presjeka na čvrstoću rotacijski zavarenog spoja. Bukov moždanik je uz pomoć frekvencije vrtnje i pomaka u smjeru uzdužne osi zavaren u podlogu izrađenu od drva obične bukve (Fagus sylvatica L.), hrasta lužnjaka (Quercus robur L.) i obične smreke (Picea abies L.) (u daljnem tekstu: bukovina, hrastovina i smrekovina). Zavarivanje se obavljalo u smjeru vlakanaca podloge (PP) $i$ okomito na njihov smjer $(R, R T, T)$.

Rezultati istraživanja pokazali su da moždanik zavaren u bukovu podlogu ima najveću čvrstoću, dokje najslabije rezultate pokazao moždanik zavaren u smrekovu podlogu. Iz rezultata istraživanja proizlazi kako bukov moždanik zavaren u smjeru vlakanaca bukove i hrastove podloge postiže najbolje rezultate glede čvrstoće spoja. Pri za-

\footnotetext{
${ }^{1}$ Authors are assistant professors, senior assistant and professor at the Faculty of Forestry, University of Zagreb, Croatia.

${ }^{1}$ Autori su docenti, viši asistent i profesor Šumarskog fakulteta Sveučilišta u Zagrebu, Zagreb, Republika Hrvatska.
} 
varivanju moždanika u smrekovinu rabljeno je i reakcijsko drvo (kompresijsko drvo četinjača) pa je raspored čvrstoće ovisno o smjeru zavarivanja bio nešto drugačiji.

Ključne riječi: zavarivanje masivnoga drva, spoj s moždanikom, vlačna čvrstoća, izvlačna sila, vrsta drva, tip presjeka

\section{INTRODUCTION}

\section{UVOD}

Suthoff and Kutzer (1997) have patented and demonstrated the rotational and vibration welding of wood. Since 2000 IBOIS (Swiss Federal Institute of Technology Lausanne) has been developing and researching the method of joining wood by friction welding without adding any adhesives (Gliniorz and Natterer, 2000; Gliniorz et al., 2001). This welding method is successfully used for joining two or more wood elements without adding glue or other adhesives. Friction wood welding is a process that causes chemical and physical reactions; the heat, which is a result of friction, melts and softens the wood structure. After cooling, the melt turns into a very hard compound. Chemical changes start with welding and continue after the process ends (while the melt solidifies). Wood structure cools down and becomes a hard compound. In this research the focus was not on the chemical changes occurring in the wood for which the authors used the knowledge from the literature at hand. The process of rotational welding produces gas emission and results in the decomposition of evaporable polymer components in the wood (Omrani et al., 2008). The analysis of evaporable compounds and gases emitted, such as smoke, which appears as a by-product during the rotational welding of the dowel to the beech and spruce base, revealed that the smoke consists of water vapour and $\mathrm{CO}_{2}$. These two are obtained by the decomposition of the components from non-crystallized lignines and some evaporable terpenes (Norway spruce). When using a zig-zag pattern of rotationally welded dowels across the interface of a butt joint between two wood planks strong joints are obtained (Omrani et al., 2007). The average tensile strength of commercial beech wood with a zig-zag pattern of rotationally welded dowels $10 \mathrm{~mm}$ in diameter (rotational movement at $1600 \mathrm{~min}^{-1}$ ) was $0.77 \pm 0.07 \mathrm{MPa}$. The results obtained also indicate that further improvement and optimization of this process should consider a minimum compression level at the end of dowel rotation.

Pizzi et al. (2004) investigated welding of a 10 $\mathrm{mm}$ diameter beech dowel to a beech base. Welding penetration was $12 \mathrm{~mm}$, rotation frequency $1200 \mathrm{~min}^{-1}$, and tightness $2 \mathrm{~mm}$. The maximum embedded force for these parameters was $1500 \mathrm{~N}$, and the average embedded force $883 \mathrm{~N}$. It was observed that welding in the tangent orientation showed the best results whereas the radial orientation had the lowest values. The average embedded force for dowels of $10 \mathrm{~mm}$ diameter inserted to $20 \mathrm{~mm}$ depth in single beech block $(30 \times 30 \times 30$ $\mathrm{mm}$ ) was $1979 \pm 103 \mathrm{~N}$ (Pizzi et al., 2006). The geometry of the dowel joint allowed the joint to retain up to $88 \%$ of its initial embedded force after $24 \mathrm{~h}$ immersion in cold water.
Dowel welding by high-speed rotation was used to join two wood blocks and strong joints were obtained (Bocquet et al., 2007). Dowel angle to the surface of the wood blocks to be joined had a marked influence on the mechanical performance of the joint. When the dowel was inserted at $90^{\circ}$ to the substrate, the dowel was subjected to and resisted a shear force only. The results obtained show that welded-dowel structural joints can satisfy both the relevant standards and outperform the equivalent nailed joints and glued-dowel joints.

Leban et al. (2008) investigated the impact of rotation frequency on the strength of a beech dowel welded to the base made of Norway spruce. For this a $12 \mathrm{~mm}$ diameter dowel was used with the frequency of $1500 \mathrm{~min}^{-1}$. The average embedded force was $2145 \mathrm{~N}$, and welding time $4 \mathrm{~s}$.

Leban et al. (2004) investigated the possibility of vibration welding of beech, oak and spruce wood with $150 \times 20 \times 30 \mathrm{~mm}$ samples, welding time of $3 \mathrm{~s}$, pressure after welding $2 \mathrm{MPa}$ during $5 \mathrm{~s}$, and constant pressure of 1.3 MPa during the welding process. The samples were welded with the frequency of $100 \mathrm{~Hz}$ and vibration amplitudes of $3 \mathrm{~mm}$. The strength of welded joints depended on the welding line thickness and balance. A thinner welding line has the ability to produce better strength compared to a thicker welding one. The average strength of a joint for breech reached 8.72 $\mathrm{MPa}$, for oak 5.43 MPa and for spruce wood 4.2 MPa. Spruce wood showed poorer welding results due to its characteristic cell implosion and crumping. This unfavourable characteristic of spruce wood influences the strength of a joint if beech and spruce wood are welded. Implosion and crumping of cell walls increases the thickness of the welding line, especially for spruce wood. Beech wood falls under the category of harder wood species and its welding line can be easily noticed because it is dark and thin, which is an indicator of a decreased implosion of the cell wall and, also of better mechanical characteristics of the joint itself.

Kanazawa et al. (2005) explored the influence of welding penetration (for a beech dowel welded to a beech base) in radial and tangent orientation on embedded force. In all analysed welding penetrations (10, 20 and $30 \mathrm{~mm}$ ), tangent orientation showed the best research results.

Ganne-Chedeville et al. 2005 researched welding of a hard wood dowel (beech) to a hard spruce wood base without drilling any holes. Research results indicate a significant dissipation of data and very intensive scuffing of the top of the dowel.

Župčić et al. (2009) investigated welding of a dowel to a base made of thermally treated and untreated hornbeam base. Thermal modification was carried out at $200{ }^{\circ} \mathrm{C}$ over 48 hours. Rotation frequency for a beech dowel was $1520 \mathrm{~min}^{-1}$. The research showed that thermally unmodified dowels welded to a hornbeam base 
(perpendicular to the fibre orientation) indicated stronger embedded force ( $84 \%$ on average, which is a statistically significant difference) than dowels welded to a thermally modified base. The average embedded force for dowels welded to an untreated base was $3754 \mathrm{~N}$.

The species of wood to which a dowel is welded is a very important factor. Thus, the objective of this paper was to investigate the influence of a wood species (beech, oak and spruce) on the strength, or embedded force, of a welded joint when a dowel is welded (in the same orientation or perpendicular to the fibre orientation) to a base. Apart from some of the factors mentioned above, the authors also looked into the influence of the welding orientation (radial, tangent and radial and tangent) on the strength of a joint.

\section{MATERIALS AND METHODS}

\section{MATERIJALI I METODE}

\subsection{Shape and dimensions of the samples 2.1. Oblik i dimenzije uzoraka}

Research in the influence of cross-sections and species of wood on the strength of a welded joint was conducted at the Faculty of Forestry of the University of Zagreb. For the purpose of this research, beech grove dowels were used and welded to beech oak and spruce bases without defect (except spruce reaction wood which was used for research). All samples were prepared by sawing, milling and shortening to the defined measure. These samples were then pierced with an $8 \mathrm{~mm}$ diameter spiral drill. Dimensions of the base to which a dowel was welded perpendicular to the fibre orientation were $200 \times 30 \times 30(\mathrm{~mm})$ with three pierces in the radial $(\mathrm{R})$, tangent $(\mathrm{T})$ and radial and tangent (RT) orientation depending on the factor under scrutiny (Figure 1). A $30 \times 30 \times 64(\mathrm{~mm})$ base with a pierce in line with the fibre orientation was used for welding a dowel in the fibre orientation. Once welded, the sample was sawn off in two identical $30 \times 30 \times 30 \mathrm{~mm}$ pieces (Figure 2). Due to elastic deformations of the wood, upon movement of the cutting edge the drill hole diameter was reduced by $0.05 \mathrm{~mm}$ on average. Dowels were grouped into $1000 \mathrm{~mm}$ sticks and had to be shortened to the correct measure. The average dowel diameter (cross-cut measures were taken on the top of the grove) was $10.04 \mathrm{~mm}$. Wood material prepared in this manner (welding base and dowels) was conditioned in a laboratory (temperature $23 \pm 2{ }^{\circ} \mathrm{C}$, relative humidity $50 \pm 5$ $\%$ ) over a six-month period. Water content was determined according to HRN ISO 3130:1999 (the Croatian standard for determining water content for testing physical and mechanical characteristics of wood). The average water content, measured after samples were dried $\left(103 \pm 2{ }^{\circ} \mathrm{C}\right)$, was $9.13 \%$ for beech wood, $9.33 \%$ for oak wood and $10.37 \%$ for spruce wood.

After determining the water content in the wood, the same probes were used for determining wood density according to HRN ISO 3131:1999 (the Croatian standard for determining wood density for testing physical and mechanical characteristics of wood). The average density for beech wood was $0.68 \mathrm{~g} / \mathrm{cm}^{3}, 0.69$ $\mathrm{g} / \mathrm{cm}^{3}$ for oak wood and $0.45 \mathrm{~g} / \mathrm{cm}^{3}$ for spruce wood.
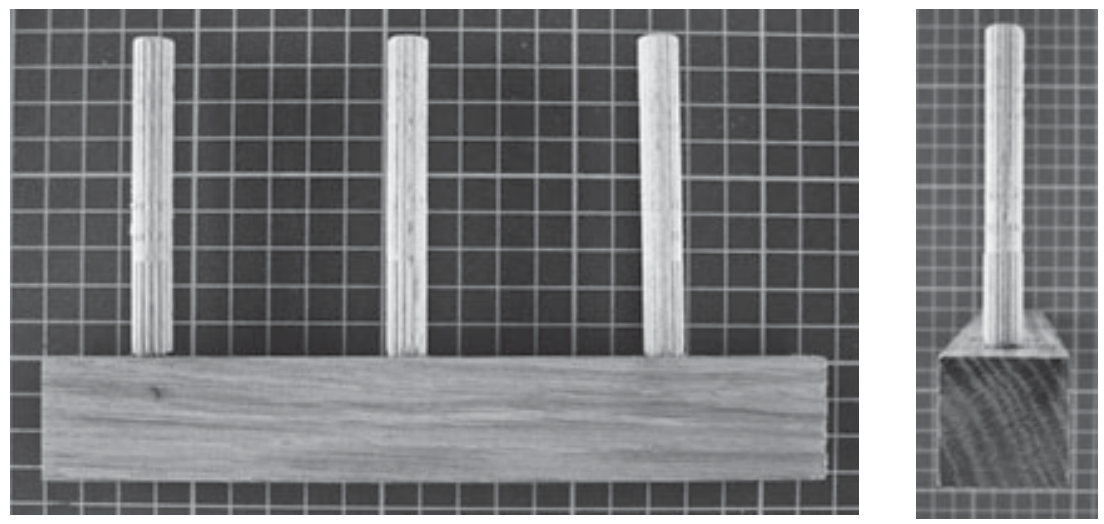

Figure 1 Test sample: Oak dowels welded perpendicular to the fibre orientation (RT)

Slika 1. Ispitni uzorak hrastovine, moždanici zavareni okomito na smjer vlakanaca (RT)

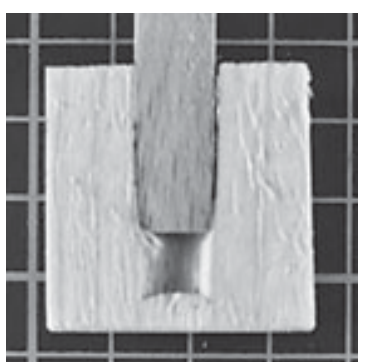

a)

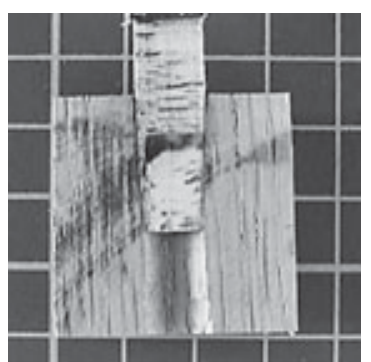

b)

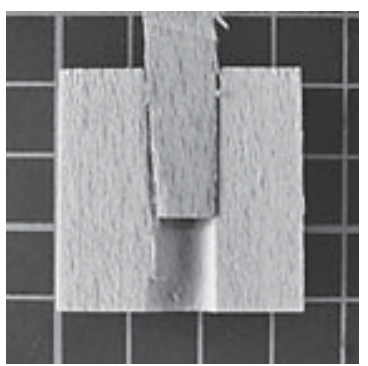

c)

Figure 2 Cross-section of the dowel welded parallel to the fibre orientation for: a) spruce; b) oak; c) beech

Slika 2. Presjek zavarenog moždanika u smjeru vlakanaca: a) u smrekovinu; b) u hrastovinu; c) u bukovinu 
Table 1 Samples used in the research

Tablica 1. Uzorci rabljeni u istraživanju

\begin{tabular}{|c|c|}
\hline $\begin{array}{l}\text { Code } \\
\text { Oznaka }\end{array}$ & Description / Opis \\
\hline BPP & $\begin{array}{l}\text { dowel welded to beech wood in the fibre orientation (transverse cross-section) } \\
\text { moždanik zavaren u bukovinu u smjeru vlakanaca (poprečni presjek) }\end{array}$ \\
\hline HPP & $\begin{array}{l}\text { dowel welded to oak wood in the fibre orientation (transverse cross-section) } \\
\text { moždanik zavaren u hrastovinu u smjeru vlakanaca (poprečni presjek) }\end{array}$ \\
\hline SPP & $\begin{array}{l}\text { dowel welded to spruce wood in the fibre orientation (transverse cross-section) } \\
\text { moždanik zavaren u smrekovinu u smjeru vlakanaca (poprečni presjek) }\end{array}$ \\
\hline $\mathrm{BR}$ & $\begin{array}{l}\text { dowel welded to beech wood perpendicular to the fibre orientation (radial orientation) } \\
\text { moždanik zavaren u bukovinu okomito na vlakanca (radijalni smjer) }\end{array}$ \\
\hline HR & $\begin{array}{l}\text { dowel welded to oak wood perpendicular to the fibre orientation (radial orientation) } \\
\text { moždanik zavaren u hrastovinu okomito na vlakanca (radijalni smjer) }\end{array}$ \\
\hline SR & $\begin{array}{l}\text { dowel welded to spruce wood perpendicular to the fibre orientation (radial orientation) } \\
\text { moždanik zavaren u smrekovinu okomito na vlakanca (radijalni smjer) }\end{array}$ \\
\hline BRT & $\begin{array}{l}\text { dowel welded to beech wood perpendicular to the fibre orientation (radial and tangent orientation) } \\
\text { moždanik zavaren u bukovinu okomito na vlakanca (radijalno-tangentni smjer) }\end{array}$ \\
\hline HRT & $\begin{array}{l}\text { dowel welded to oak wood perpendicular to the fibre orientation (radial and tangent orientation) } \\
\text { moždanik zavaren u hrastovinu okomito na vlakanca (radijalno-tangentni smjer) }\end{array}$ \\
\hline SRT & $\begin{array}{l}\text { dowel welded to spruce wood perpendicular to the fibre orientation (radial and tangent orientation) } \\
\text { moždanik zavaren u smrekovinu okomito na vlakanca (radijalno-tangentni smjer) }\end{array}$ \\
\hline BT & $\begin{array}{l}\text { dowel welded to beech wood perpendicular to the fibre orientation (tangent orientation) } \\
\text { moždanik zavaren u bukovinu okomito na vlakanca (tangentni smjer) }\end{array}$ \\
\hline HT & $\begin{array}{l}\text { dowel welded to oak wood perpendicular to the fibre orientation (tangent orientation) } \\
\text { moždanik zavaren } u \text { hrastovinu okomito na vlakanca (tangentni smjer) }\end{array}$ \\
\hline ST & $\begin{array}{l}\text { dowel welded to spruce wood perpendicular to the fibre orientation (tangent orientation) } \\
\text { moždanik zavaren u smrekovinu okomito na vlakanca (tangentni smjer) }\end{array}$ \\
\hline $\mathrm{PP}$ & transversal cross-section / poprečni presjek \\
\hline $\mathrm{T}$ & tangent cross-section / tangentni presjek \\
\hline $\mathrm{R}$ & radial cross-section / radijalni presjek \\
\hline RT & radial - tangent cross-section / radijalno-tangentni presjek \\
\hline
\end{tabular}

In total 365 samples were welded, and 359 samples were then used for further research. The code of samples used in the research is described in Table 1. Six samples started cracking during the welding process and were dismissed from further analysis. Welding penetration was $20 \mathrm{~mm}$ with constant rotation frequency of $1520 \mathrm{~min}^{-1}$. The same pressure to the joint elements was kept after rotation for three seconds on average (min. two, max. four seconds). The average welding tightness was $2.09 \mathrm{~mm}$.

\subsection{Test of embedded force}

\subsection{Ispitivanje izvlačne sile}

Tests on beech dowels rotationally welded to the base made of beech, oak and spruce wood were performed on the universal mechanical testing machine at the Faculty of Forestry of the University of Zagreb with testing time interval of $5 \mathrm{~mm} / \mathrm{min}$. A computer was used for measuring the force and displacement, and all values were accurately determined to the accuracy of $5 \mathrm{~N}$. This research used 359 samples in total, which were welded precisely without any cracks caused by the welding process or any other errors.

\section{RESULTS AND DISCUSSION}

\section{REZULTATI I RASPRAVA}

The research results presented in Table 2 and Figure 3 indicate that the species of wood and orientation of dowel welding (parallel and vertical to the fibre orientation) have a considerable effect on embedded force, that is the strength of a joint (with identical welding parameters used for all samples and under assumption that the joint surface is also identical). The best results for the embedded force were found in beech samples with a dowel welded to transverse cross-section, or in the wood fibre orientation (5144.8 $\mathrm{N}$ on average), which was expected. There is a significant statistical difference (Table 3) between dowels welded parallel and perpendicular to the fibre orientation. In dowels welded perpendicular to the fibre orientation (R, T, RT), values for embedded force did not indicate any significant statistical difference (Table 3). Župčić (2010) conducted tests in order to investigate the influence of the welding orientation on dowels welded to a beech base and obtained very similar distribution of embedded force values. When welding grove dowels in the conditions described above, welded dowel surface is $560 \mathrm{~mm}^{2}$, which is $16 \%$ less compared to the surface before welding (Župčić, 2010). The average strength of welded joints in beech was 8.7 $\mathrm{N} / \mathrm{mm}^{2}$ and of glued joints $8.0 \mathrm{~N} / \mathrm{mm}^{2}$.

Distribution of embedded force values measured on oak and beech samples indicated very similar results; the only difference is that the values were lower with a significant statistical difference. The average embedded force value measured on dowels welded to the oak base parallel to the fibre orientation (PP) was 
Table 2 Descriptive statistics for embedded force depending on wood species and cross-section

Tablica 2. Deskriptivna statistika izvlačne sile u ovisnosti o vrsti drva i presjeku

\begin{tabular}{|l|c|c|c|c|c|c|c|c|}
\hline \multirow{2}{*}{$\begin{array}{c}\text { Code } \\
\text { Oznaka } \\
\text { uzorka }\end{array}$} & $\begin{array}{c}\text { Number } \\
\text { of } \\
\text { samples } \\
\text { Broj } \\
\text { uzoraka }\end{array}$ & $\begin{array}{c}\text { Means } \\
\text { Aritmetička } \\
\text { sredina } \\
\text { izvlačne sile } \\
\text { N }\end{array}$ & $\begin{array}{c}\text { Std. Dev. } \\
\text { Standardna } \\
\text { devijacija } \\
\text { izvlačne sile }\end{array}$ & $\begin{array}{c}\text { Minimum } \\
\text { Minim. } \\
\text { izvlačna sila }\end{array}$ & $\begin{array}{c}\text { Maximum } \\
\text { Maks. } \\
\text { izvlačna sila }\end{array}$ & $\begin{array}{c}\text { Q25 } \\
\text { Izvlačna } \\
\text { sila Q25 }\end{array}$ & $\begin{array}{c}\text { Median } \\
\text { Izvlačna } \\
\text { sila medijan }\end{array}$ & $\begin{array}{c}\text { Q75 } \\
\text { Izvlačna sila } \\
\text { Q75 }\end{array}$ \\
\hline BPP & 31 & 5144.8 & 518.1 & 4190 & 6280 & 4660 & 5300 & N \\
\hline HPP & 30 & 4477.3 & 389.9 & 3560 & 5190 & 4240 & 4520 & 4750 \\
\hline SPP & 32 & 1410.6 & 298.6 & 900 & 2220 & 1220 & 1355 & 1595 \\
\hline BR & 30 & 4778.3 & 309.8 & 4300 & 5330 & 4520 & 4760 & 5050 \\
\hline HR & 28 & 4166.8 & 370.6 & 3420 & 4850 & 3925 & 4180 & 4440 \\
\hline SR & 28 & 2674.3 & 508.5 & 1900 & 3650 & 2250 & 2645 & 3105 \\
\hline BRT & 30 & 4754.0 & 460.9 & 3150 & 5750 & 4610 & 4710 & 5040 \\
\hline HRT & 30 & 3961.3 & 428.7 & 3020 & 4990 & 3660 & 3995 & 4190 \\
\hline SRT & 30 & 1924.3 & 185.0 & 1540 & 2240 & 1780 & 1945 & 2040 \\
\hline BT & 30 & 4846.7 & 338.4 & 4040 & 5540 & 4680 & 4810 & 5060 \\
\hline HT & 30 & 4000.3 & 385.0 & 3280 & 4610 & 3640 & 4020 & 4220 \\
\hline ST & 30 & 2688.3 & 824.1 & 1350 & 4200 & 2060 & 2370 & 3700 \\
\hline All groups & 359 & 3730.1 & 1285.9 & 900 & 6280 & 2400 & 4130 & 4700 \\
Sve grupe & & & & & & & & $\mathrm{N}$ \\
\hline
\end{tabular}

4477.3 N, or $13 \%$ less than the values for beech samples. There is a significant statistical difference between dowels welded parallel and perpendicular to the fibre orientation. In dowels welded perpendicular to the fibre orientation (R, T, RT), embedded force values did not reveal any significant statistical difference.

Spruce samples indicated significantly different value distribution since reaction wood had been used for the preparation of samples. The largest average value of embedded force in ST and SR spruce samples was recorded in samples with reaction wood, and the smallest in SPP samples without reaction wood. It can be concluded that the reaction wood increases the embedded force of the above mentioned samples in comparison with SPP samples. It is a well-known fact that reaction spruce wood has much wider growth rings with a larger share of late wood resulting in higher density. Reaction spruce wood also has a larger portion of higher lignine content and lower cellulose content. The research results (Župčić, 2010) indicate that differences in density for the same wood species influence the strength of a welded joint where an increased density results in an increased strength of a welded joint. Chemical, physical and mechanical changes also influence the strength of a welded joint. However, this is not the focus of this research.

The average embedded force value for dowels welded to the spruce base parallel to the fibre orientation (PP) was $1410.6 \mathrm{~N}$ or $73 \%$ less than the value for beech samples or $68 \%$ less than the value for oak wood. Spruce wood indicated lower welding results due to its characteristic implosion and crumpling of cell walls (Lebanet al., 2004). During welding time a dowel volume decreased whereas the hole volume increased with two side-effects: cell walls implode, and interface surface density increases from its regular values which are up to $1.4 \mathrm{~g} / \mathrm{cm}^{3}$ (Pizzi et al., 2004). The

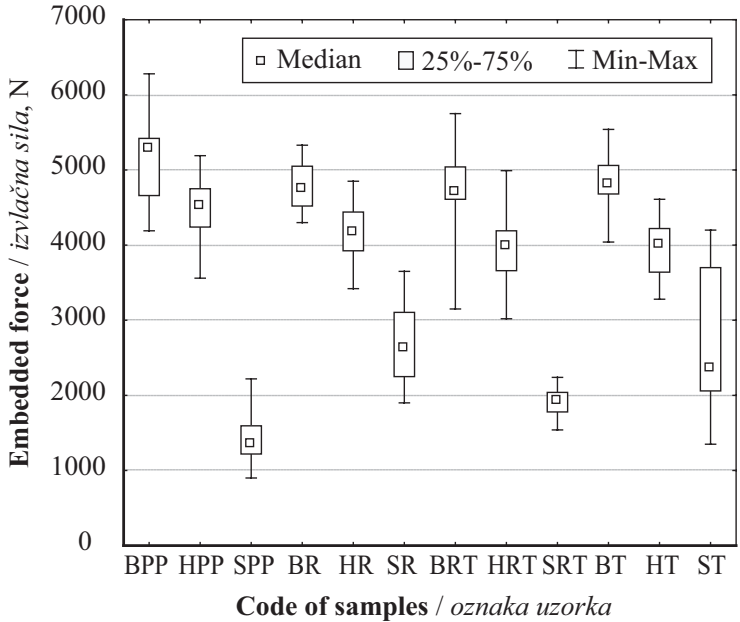

Figure 3 Influence of wood species and cross-section on embedded force

Slika 3. Utjecaj vrste i presjeka drva na izvlačnu silu

other part of the volume vanishes due to frictional abrasion (of the dowel and side walls inside the hole) and draining of the melt from the interface zone. When the beech dowels was welded to the beech base parallel to the fibre orientation, the zone of implosion of cell walls exceeded $1.5 \mathrm{~mm}$ (Župčić, 2010).

The research was also focused on the influence of ring thickness in SR and ST samples. The research results (Figure 4) indicate that the embedded force decreases with the increase of the number of growth rings, i.e. the decrease of growth ring width and share of late wood. It should be assumed that the width of growth rings in reaction spruce wood influences the strength of a welded joint. For the purpose of further researching this area, it is necessary to provide more samples and to research in detail the influence of reaction wood on the strength of joints. Dependency of embedded force and 
Table 3 Multiple comparison rankings (Kruskal-Wallis test: $H(11, N=359)=297.9809 p=0.000$ )

Tablica 3. Višestruka usporedba rangova (Kruskal-Wallis test: $H(11, N=359)=297,9809 p=0,000$ )

\begin{tabular}{|l|c|c|c|c|c|c|c|c|c|c|c|c|}
\hline $\begin{array}{c}\text { Code } \\
\text { Oznaka } \\
\text { uzorka }\end{array}$ & $\begin{array}{c}\text { BPP } \\
\text { R:308.4 }\end{array}$ & $\begin{array}{c}\text { HPP } \\
\text { R:233.7 }\end{array}$ & $\begin{array}{c}\text { SPP } \\
\text { R:20.4 }\end{array}$ & $\begin{array}{c}\text { BR } \\
\text { R:274.8 }\end{array}$ & $\begin{array}{c}\text { HR } \\
\text { R:189.5 }\end{array}$ & $\begin{array}{c}\text { SR } \\
\text { R:92.6 }\end{array}$ & $\begin{array}{c}\text { BRT } \\
\text { R:271.7 }\end{array}$ & $\begin{array}{c}\text { HRT } \\
\text { R:167.9 }\end{array}$ & $\begin{array}{c}\text { SRT } \\
\text { R:50.9 }\end{array}$ & $\begin{array}{c}\text { BT } \\
\text { R:285.3 }\end{array}$ & $\begin{array}{c}\text { HT } \\
\text { R:171.1 }\end{array}$ & $\begin{array}{c}\text { ST } \\
\text { R:94.4 }\end{array}$ \\
\hline BPP & & 0.3263 & 0.0000 & 1.0000 & 0.0007 & 0.0000 & 1.0000 & 0.0000 & 0.0000 & 1.0000 & 0.0000 & 0.0000 \\
\hline HPP & 0.3263 & & 0.0000 & 1.0000 & 1.0000 & 0.0000 & 1.0000 & 0.9330 & 0.0000 & 1.0000 & 1.0000 & 0.0000 \\
\hline SPP & 0.0000 & 0.0000 & & 0.0000 & 0.0000 & 0.4742 & 0.0000 & 0.0000 & 1.0000 & 0.0000 & 0.0000 & 0.3306 \\
\hline BR & 1.0000 & 1.0000 & 0.0000 & & 0.1161 & 0.0000 & 1.0000 & 0.0044 & 0.0000 & 1.0000 & 0.0072 & 0.0000 \\
\hline HR & 0.0007 & 1.0000 & 0.0000 & 0.1161 & & 0.0316 & 0.1686 & 1.0000 & 0.0000 & 0.0291 & 1.0000 & 0.0324 \\
\hline SR & 0.0000 & 0.0000 & 0.4742 & 0.0000 & 0.0316 & & 0.0000 & 0.3789 & 1.0000 & 0.0000 & 0.2638 & 1.0000 \\
\hline BRT & 1.0000 & 1.0000 & 0.0000 & 1.0000 & 0.1686 & 0.0000 & & 0.0070 & 0.0000 & 1.0000 & 0.0114 & 0.0000 \\
\hline HRT & 0.0000 & 0.9330 & 0.0000 & 0.0044 & 1.0000 & 0.3789 & 0.0070 & & 0.0008 & 0.0007 & 1.0000 & 0.4018 \\
\hline SRT & 0.0000 & 0.0000 & 1.0000 & 0.0000 & 0.0000 & 1.0000 & 0.0000 & 0.0008 & & 0.0000 & 0.0004 & 1.0000 \\
\hline BT & 1.0000 & 1.0000 & 0.0000 & 1.0000 & 0.0291 & 0.0000 & 1.0000 & 0.0007 & 0.0000 & & 0.0013 & 0.0000 \\
\hline HT & 0.0000 & 1.0000 & 0.0000 & 0.0072 & 1.0000 & 0.2638 & 0.0114 & 1.0000 & 0.0004 & 0.0013 & & 0.2785 \\
\hline ST & 0.0000 & 0.0000 & 0.3306 & 0.0000 & 0.0324 & 1.0000 & 0.0000 & 0.4018 & 1.0000 & 0.0000 & 0.2785 & \\
\hline
\end{tabular}

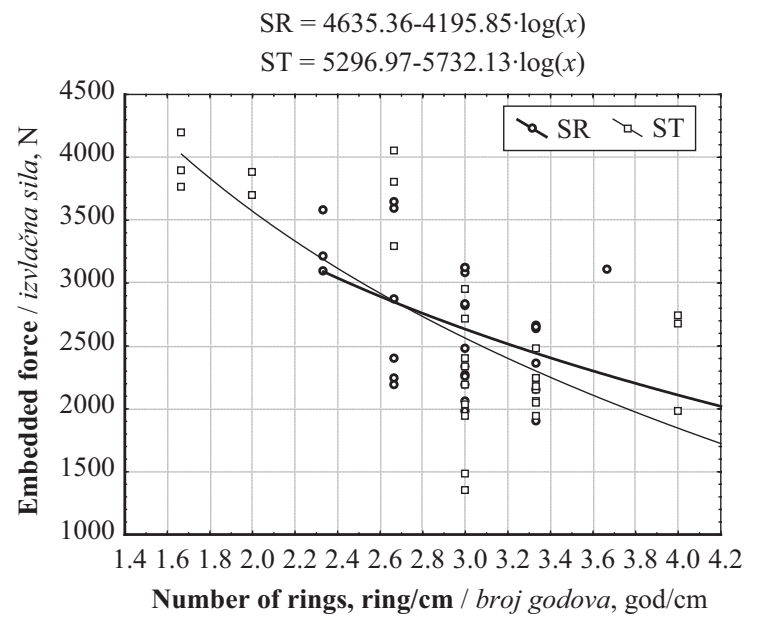

Figure 4 Influence of the number of growth rings (SR and ST) to embedded force

Slika 4. Utjecaj broja godova (SR i ST) na izvlačnu silu

number of growth rings of SR samples may be described by the following equation: $y=4635.36-4195.84 \cdot \log x$, while ST samples may be described by the equation where $y=5296.97-5732.13 \cdot \log x$.

Figure 5 indicates a slow growth for beech wood and a mild drop for oak wood in respect of embedded force with decreased width of growth rings (where the number of growth rings per centimetre increased). The influence of growth ring width has not been unequivocally determined, as indicated in the research papers (Župčić, 2010). Growth ring width has an effect on the strength of a joint but it is not statistically relevant. Beech and oak wood are species of wood with important differences in anatomic, physical, mechanical and chemical characteristics depending on the biotope, soil, altitude and position in the tree. These factors influenced the dissipation of data because the samples had been selected from the regular production of edge glued panels. Dependency of embedded force and number of growth rings for BRT samples may be described by the following equation: $y=4127.64+$ $1140.08 \cdot \log x$, while HRT samples may be described by the equation where $y=4140.33-280.97 \cdot \log x$.

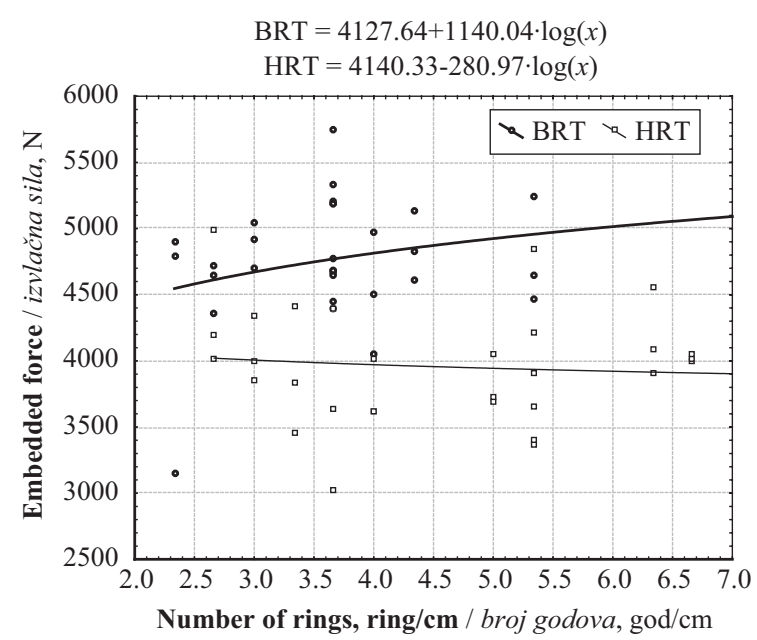

Figure 5 Influence of the number of growth rings (BRT and HRT) on embedded force

Slika 5. Utjecaj broja godova (BRT i HRT) na izvlačnu silu

\section{CONCLUSION \\ 4. ZAKLJUČAK}

Rotational welding can be successfully used for welding beech grove dowels to bases made of beech, oak and spruce wood parallel and perpendicular to the fibre orientation. The research results lead to the conclusion that the influence of wood species and welding orientation on the strength of a welded joint is statically relevant.

The research results reveal that beech wood is the best wood species for welding dowels, regardless of the fibre orientation - parallel or vertical. Statistically significant differences (Table 3) appear for all combinations except for oak wood welded to a transverse cross-section or perpendicular to the fibres in the radial orientation.

The average values for the embedded force measured in dowels welded to spruce wood are statistically significantly lower in relation to the average values for the embedded force measured in dowels welded to beech and oak wood. Such results were expected because of spruce wood structure, composition and other characteristics. Reaction wood also has a 
significant influence since it improves the strength of a welded joint.

Dowels welded parallel to the fibre orientation indicated higher values for the embedded force than dowels welded perpendicular to the fibre orientation (beech and oak wood test samples). Tests on spruce wood indicated that dowels welded perpendicular to the fibre orientation have stronger embedded force than dowels welded parallel to the fibre orientation due to the reaction wood which is known for its higher density and higher proportion of late wood.

Width of a growth ring does not have much statistical significance except for spruce wood (reaction wood) for which the embedded force grows with the increase of growth ring width.

\section{REFERENCES}

\section{LITERATURA}

1. Bocquet, J. F.; Pizzi , A.; Despres, A., Mansouri, H. R.; Resch, L.; Michel, D.; Letort, F., 2007: Wood joints and laminated wood beams assembled by mechanicallywelded wood dowels. J. Adhesion Sci. Technol., 21 (34): 301-317. http://dx.doi.org/10.1163/156856107780684585.

2. Ganne-Chedeville, C.; Pizzi, A.; Thomas, A.; Leban, J. M.; Bocquet, J. F.; Despres, A.; Mansouri, H., 2005: Parameter interactions in two-block welding and the wood nail concept in wood dowel welding. J Adhesion Sci. Technol., 19 (13-14): 1157-1174. http://dx.doi.org/10.1163/156856105774429037.

3. Gliniorz, K. U.; Natterer, J., 2000: Holzschweißen - Innovative Verbindungs-technologien in Holzbau. Symposium der ligna Plus/Weltmesse für die Forst- und Holzwirtschaft in Hannover, 9-18.

4. Gliniorz, K. U.; Mohr, S.; Natterer, J.; Navi, P., 2001: Wood Welding. Proceedings of the 1st International Conference of the European Society for Wood Mechanics, Lausanne, Switzerland, 571-574.

5. Kanazawa, F.; Pizzi, A., Properzi, M.; Delmotte, L.; Pichelin, F., 2005: Parameters influencing wood-dowel welding by high-speed rotation. J. Adhesion Sci. Technol., 19 (12): 1025-1038. http://dx.doi.org/10.1163/156856105774382444.

6. Leban, J. M.; Pizzi, A.; Wieland, S.; Zanetti, M.; Properzi, M.; Pichelin, F., 2004: X-ray microdensitometry analysis of vibration-welded wood. J. Adhesion Sci. Technol., 18 (6): 673-685.

http://dx.doi.org/10.1163/156856104839310.
7. Leban, J. M.; Mansouri, H. R.; Omrani, P.; Pizzi, A., 2008: Dependence of dowel welding on rotation rate. Holz Roh Werkst., 66: 241-242. http://dx.doi.org/10.1007/s00107-008-0228-6.

8. Omrani, P.; Bocquet, J. F.; Pizzi, A..; Leban, J. M.; Mansouri, H., 2007: Zig-zag rotational dowel welding for exterior wood joints. J. Adhesion Sci. Technol., 20 (10): 923-933. http://dx.doi.org/10.1163/156856107781393910.

9. Omrani, P.; Masson, B.; Pizzi, A.; Mansouri, H. R., 2008: Emission of gases and degradation volatiles from polymeric wood constituents in friction welding of wood dowels. Elsevier, Polymer Degradation and Stability, 93: 794-799. http://dx.doi.org/10.1016/j.polymdegradstab.2008.01.017.

10. Pizzi, A.; Leban, J. M.; Kanazawa, F.; Properzi, M.; Pichelin, F., 2004: Wood dowel bonding by high-speed rotation welding. J. Adhesion Sci. Technol., 18 (11): 1263-1278. http://dx.doi.org/10.1163/1568561041588192.

11. Pizzi, A.; Despres, A.; Mansouri, H. R.; Leban, J. M.; Rigolet, S., 2006: Wood joints by through-dowel totation welding: microstrukture, $13 \mathrm{C}-\mathrm{NHR}$ and water resistante. J. Adhesion Sci. Technol., 20 (5): 427-436. http://dx.doi.org/10.1163/156856106777144327.

12. Suthoff, B., Kutzer, H. J., 1997: German Patent DE 197 $46782 \mathrm{~A}$.

13. Župčić, I.; Mihulja, G.; Govorčin, S.; Bogner, A.; Grbac, I.; Hrovat, B., 2009: Zavarivanje termički modificirane grabovine. Drvna industrija, 60(3): 161-166.

14. Župčić, I., 2010: Čimbenici koji utječu na spajanje bukovih tokarenih elemenata tehnikom zavarivanja. Sveučilište u Zagrebu, Šumarski fakultet, disertacija, 1-237.

15. *** HRN ISO 3130:1999 (hrvatska norma za određivanje sadržaja vode za ispitivanje fizikalnih i mehaničkih svojstava drva).

16. *** HRN ISO 3131:1999 (hrvatska norma za određivanje gustoće drva za ispitivanje fizikalnih i mehaničkih svojstava drva).

\section{Corresponding address:}

Assistant professor IVICA ŽUPČIĆ, Ph.D.

University of Zagreb

Faculty of Forestry

Svetošimunska 25, p.p. 422

HR-10002 Zagreb, CROATIA

e-mail: izupcic@sumfak.hr 